\title{
Pore Structure and Permeation Properties of Kaolin-Silica-Alumina Ceramics
}

\author{
Yung-Feng CHEN, Moo-Chin WANG* and Min-Hsiung HON \\ Department of Materials Science and Engineering, National Cheng Kung University, 1, Ta-Hsueh Road, Tainan 70101, Taiwan \\ *Department of Mechanical Engineering, National Kaohsiung University of Applied Sciences, 415, Chien-Kung Road, Kaohsiung 80782, Taiwan
}

\author{
カオリン-シリカ-アルミナセラミックスの気孔及び浸透構造 \\ 陳＼cjkstart永鋒·王木琴*·洪 敏雄 \\ 国立成功大学材料科学及工程学系, 70101 中華民国台湾台南市大学路 1 \\ *国立高雄応用科技大学機械工程系，80782 中華民国台湾高雄市建功路 415
}

\begin{abstract}
The pore structure and permeation properties of kaolin-silica (quartz)-alumina (corundum) ceramics have been investigated using kaolin, $\mathrm{SiO}_{2}$ and $\mathrm{Al}_{2} \mathrm{O}_{3}$ powders as staring materials. The $\mathrm{Al}_{2} \mathrm{O}_{3}$ powders used are of different particle sizes, 0.8 and $4.0 \mu \mathrm{m}$. Mullite phase appears at approximately $1373 \mathrm{~K}$ and mullite phase content in the sintered samples increases with the increase in sintering temperature from 1373 to $1573 \mathrm{~K}$ for $1 \mathrm{~h}$. Open porosity decreases from 48.4 and $46.8 \%$ to $32.3 \%$ for the 0.8 - and $4.0-\mu \mathrm{m} \mathrm{Al}_{2} \mathrm{O}_{3}$ powders, respectively. The maximum average pore sizes have been noted to be 0.51 - and $0.63-\mu \mathrm{m}$ for the 0.8 - and $4.0-\mu \mathrm{m} \mathrm{Al}_{2} \mathrm{O}_{3}$ powders as-sintered at $1473 \mathrm{~K}$, respectively. The maximum penetrating porosity is $24.1 \%$ for the $0.8-\mu \mathrm{m} \mathrm{Al}_{2} \mathrm{O}_{3}$ powder as-sintered at $1473 \mathrm{~K}$; it decreases with the increase in temperature for the $4.0-\mu \mathrm{m} \mathrm{Al}_{2} \mathrm{O}_{3}$ powder. The tortuosity of the $0.8-\mu \mathrm{m} \mathrm{Al}_{2} \mathrm{O}_{3}$ powder does not change significantly, but that of the $4.0-\mu \mathrm{m} \mathrm{Al}_{2} \mathrm{O}_{3}$ powder decreases from 0.85 to 0.29 with the increase in sintering temperature. Seemingly, the mullite-based filtration material has been shown to be more efficient and durable than conventional polymeric and diatomite materials.

[Received September 30, 2002; Accepted May 26, 2003]
\end{abstract}

Key-words : $\mathrm{Kaolin}-\mathrm{SiO}_{2}-\mathrm{Al}_{2} \mathrm{O}_{3}$ ceramics, Pore structure, Permeation

1. Introduction

Much attention has been given to highly porous filters due to the increasing demand for environmentally friendly devices, which is demonstrated by the operation of crossflow filtration intended for the efficient removal of suspended contaminants from aqueous solutions. The wide range of applications of such filters includes the removal of suspended solids, filth and dirt from water, wastewater treatment and resource recycling. The decline in flux or permeation rate is believed to be the major limitation to the widespread implementation of cross-flow filtration in the wastewater treatment industry. ${ }^{1)}$ The fluid permeability of porous materials depends on open porosity, pore size and the tortuosity of pore networks. With a higher open porosity and a narrower pore size distribution, a filter shows higher liquid permeability and separation efficiency.

Depending on specific applications, various materials have been used in the preparation of membrane devices. Most of the filtering membranes presently used are made of polymeric materials; however, their use is limited to a maximum operation temperature of $353 \mathrm{~K}^{2}{ }^{2}$ In recent years, heat-resistant ceramic membranes made of various oxides such as $\alpha$-alumina, mullite, cordierite, silica and zirconia, and also non-oxides such as silicon carbide and silicon nitride have been fabricated. These ceramic materials have gained ground in replacing conventional polymeric membranes. ${ }^{3)-5)}$ As such, the properties of the starting powder are important factors in the preparation of porous materials. Triple-component systems consisting of kaolin, feldspar and $\alpha-\mathrm{Al}_{2} \mathrm{O}_{3}$ (or quartz in place of $\alpha-\mathrm{Al}_{2} \mathrm{O}_{3}$ ) are generally used in conventional ceramic technology. ${ }^{6}$ Porous green bodies can be obtained by dry and wet processes. The dry mode of the forming process of pressure molding may be more easily conducted but it cannot provide a high porosity and a uniform pore size distribution. On the other hand, wet methods such as extrusion, tape casting and injection molding are complicated processes but are suitable for products with a high porosity and a uniform pore size distribution.

Since the amount of $\mathrm{SiO}_{2}$ in kaolin is much higher than that in mullite, excess $\mathrm{SiO}_{2}$ together with the impurities in kaolin forms a glassy phase and cristobalite with the formation of mullite at temperatures higher than $1273 \mathrm{~K} .{ }^{7)}$ Several review articles have described the general results of using alumina, ${ }^{8,9)}$ kaolin (or kaolinite), ${ }^{10)}$ or kaolin-alumina ${ }^{11)-13 \text { ) }}$ as starting powders in preparing membranes and studying the properties of these materials. On the other hand, the effect of $\mathrm{Al}_{2} \mathrm{O}_{3}$ and glass additives on the formation of needle like mullite from kaolin was also reported by Matsuda et al. ${ }^{14)}$ The yield of mullite produced by firing a mixture of kaolin, alumina and $\mathrm{SiO}_{2}$ increases rapidly above $1573 \mathrm{~K}$ as compared with that produced by firing kaolin alone. However, the mullite particles obtained by firing the kaolin-alumina mixture are granular. Glass improves the formation of needle-like mullite in a kaolin-alumina- $\mathrm{SiO}_{2}$ mixture. Kanka et al.15) showed the microstructural development of coprecipitated mullite with a stiff skeleton of tabular mullite crystals that could hinder shrinkage rendering a higher porosity. Summing up, further studies are needed to provide some detailed information on the pore structure and glassy phase formation for the kaolin- $\mathrm{SiO}_{2}$ (quartz) $-\mathrm{Al}_{2} \mathrm{O}_{3}$ (corundum) powder using a combination of ceramic extrusion molding and sintering.

In the present investigation, green pipes were prepared with a mixture of raw materials consisting of kaolin, $\mathrm{SiO}_{2}$ and $\mathrm{Al}_{2} \mathrm{O}_{3}$ powders of two different particle sizes as well as binders by an extrusion molding process commonly used in ceramic fabrication. The main purpose of this study is to examine the effect of the addition of $\mathrm{Al}_{2} \mathrm{O}_{3}$ of two different particle sizes $(0.8$ and $4.0 \mu \mathrm{m})$ on the pore structure and phase development of the mullite ceramic prepared using kaolin- $\mathrm{SiO}_{2}-\mathrm{Al}_{2} \mathrm{O}_{3}$ by X-ray diffraction (XRD) analysis, scanning electron microscopy (SEM), transmission electron microscopy (TEM) and mercury porosimetry. 


\section{Experimental procedure}

2.1 Raw materials and sample preparation

The kaolin, $\mathrm{SiO}_{2}$ (quartz) and $\mathrm{Al}_{2} \mathrm{O}_{3}$ (corundum) powders used as raw materials were supplied by Akima Co. (Malaysia, AKIMA-25, average size $1.3 \mu \mathrm{m}$ ), Katayama Chem. (Japan, average size $4.8 \mu \mathrm{m}$ ) and Sumitomo Chem. (Japan, AES-21, average size $0.8 \mu \mathrm{m}$ and AM-21, average size $4 \mu \mathrm{m})$, respectively. Kaolin powder contains kaolinite, mica, quartz and several kinds of impurity such as potassium, iron and magnesium oxides. Kaolinite consists of hydrated aluminosilicates that are fine-grained and usually have a platy or flaky feature which make them stack together to form agglomerates. The mixture of raw materials was calcined at $673 \mathrm{~K}$ for $6 \mathrm{~h}$ to remove water and organic materials. All specimens were derived from element powders to which a 30.5 mass\% multiple-organic solution as a binder consisting of 23.0 mass\% PEG-10 k, 4.6 mass\% glycerin, 31.8 mass\% selosol 920, 4.6 mass\% Celuna D-305 and 36.1 mass $\%$ deionized water was added. The properties of the starting powders, the characteristics of each constituent as a multiple-organic solution and a binder are listed in Tables 1-4.

The raw materials consisting of 38.2 mass $\%$ calcined kaolin, 3.5 mass $\% \mathrm{SiO}_{2}$ and 27.8 mass $\% \mathrm{Al}_{2} \mathrm{O}_{3}$ powders were first blended for $1 \mathrm{~h}$ using a laboratory mixer. A batch $(1.0$ $\mathrm{kg}$ ) of admixed raw materials with 30.5 mass \% multiple-organic solution was mixed using a double- $Z$ blade at $298 \mathrm{~K}$ for $0.5 \mathrm{~h}$; subsequently, the resulting feedstocks were extrusion-molded at $10 \mathrm{MPa}$ using a single-screw extruder at a temperature of $298 \mathrm{~K}$ to obtain a pipe sample of $3 \times 10^{-2} \mathrm{~m}$ radius, $0.5 \times 10^{-2} \mathrm{~m}$ thickness and $10 \times 10^{-2} \mathrm{~m}$ length.

In thermal debinding, the water constituent was preferentially removed at $383 \mathrm{~K}$ for $0.5 \mathrm{~h}$. Glycerin, selosol 920 and celuna D-305 were extracted at about $443 \mathrm{~K}$ for $1 \mathrm{~h}$. The samples were then heated to $748 \mathrm{~K}$ at a heating rate of $1 \mathrm{~K}$. $\mathrm{min}^{-1}$ and held for $0.5 \mathrm{~h}$ for PEG-10 $\mathrm{k}$ debinding. Finally, the debinded samples were sintered at $1373-1573 \mathrm{~K}$ for $1 \mathrm{~h}$ at a heating rate of $5 \mathrm{~K} \cdot \mathrm{min}^{-1}$.

\subsection{Sample characterization}

Open porosity was measured by the Archimedes method using samples of $0.5 \times 0.5 \times 1.0 \times 10^{-6} \mathrm{~m}^{3}$ dimensions cut from a large extruded pipe. Pore size distribution was measured using mercury porosimetry equipment (Autopore II 9220, Micromeritics, USA).

Penetrating porosity was determined by the following procedure: The top of a $0.1 \mathrm{~m}$ long pipe sample was sealed with a stainless-steel tank. Deionized water was introduced into an opening at the bottom of the tank and penetrated the sample. The time required for a known volume of water to pass through the sample under applied pressures of 0.1-0.3 $\mathrm{MPa}$ was measured. The average volume flow rate $(Q)$ of three runs at each pressure was plotted against applied pressure $(p)$. The coefficient of specific permeability $\left(K_{\mathrm{p}}\right)$ can be expressed as ${ }^{16)}$

$$
K_{\mathrm{p}}=\left(\mathrm{d} Q \cdot \mathrm{d} p^{-1}\right) \eta L A^{-1}
$$

where $\mathrm{d} Q \cdot \mathrm{d} p^{-1}$ is the slope of the curve of average volume flow rate versus applied pressure, $\eta$ is the viscosity of the liquid medium, and $L$ and $A$ are the thickness and cross-sectional area of the sintered samples, respectively. In general, for the liquid permeation of microporous materials, Darcy's law based on Poiseuille's law is used in determining laminar flow through porous materials. Penetrating porosity $\left(\varepsilon_{\text {eff }}\right)$ dependent on the flow rate of the liquid medium and average pore radius $(r)$ can be calculated using: ${ }^{16), 17)}$

$$
\varepsilon_{\text {eff }}=24\left(\mathrm{~d} Q \cdot \mathrm{d} p^{-1}\right) \eta L A^{-1} r^{-2}
$$

The procedure for determining the amount (weight fraction) of glassy phase is given below. The HF acid leaching
Table 1. Chemical Composition of Kaolin and $\mathrm{SiO}_{2}$ (Quartz) Powders after Calcination at $673 \mathrm{~K}$ for $6 \mathrm{~h}$

\begin{tabular}{lc|cc}
\hline \multicolumn{2}{c|}{ Kaolin } & \multicolumn{2}{c}{$\mathrm{SiO}_{2}$} \\
\hline \multicolumn{2}{c|}{ Composition $/$ mass \% } & \multicolumn{2}{c}{ Composition / mass \% } \\
\hline $\mathrm{SiO}_{2}$ & 54.00 & $\mathrm{Sl}$ & 99.90 \\
$\mathrm{Al}_{2} \mathrm{O}_{3}$ & 32.00 & $\mathrm{SO}_{4}$ & 0.01 \\
$\mathrm{Fe}_{2} \mathrm{O}_{3}$ & 0.98 & $\mathrm{~Pb}$ & 0.07 \\
$\mathrm{TiO}_{2}$ & 0.45 & $\mathrm{Fe}$ & 0.01 \\
$\mathrm{CaO}^{2}$ & 0.06 & & 0.01 \\
$\mathrm{~K}_{2} \mathrm{O}$ & 1.65 & & \\
$\mathrm{Na}$ & 0.25 & & \\
$\mathrm{MgO}$ & 0.30 & \\
Ignition Loss & 10.31 & \\
\hline
\end{tabular}

Table 2. Chemical Composition and Mean Particle Size of $\alpha-\mathrm{Al}_{2} \mathrm{O}_{3}$ (Corundum) Powder after Calcination at $673 \mathrm{~K}$ for $6 \mathrm{~h}$

\begin{tabular}{lccc}
\hline \hline & & AES-21 & AM-21 \\
\hline Chemical & $\mathrm{Fe}_{2} \mathrm{O}_{3}$ & 0.04 & 0.02 \\
Composition & $\mathrm{SiO}_{2}$ & 0.02 & 0.02 \\
mass \% & $\mathrm{Na}_{2} \mathrm{O}$ & 0.04 & 0.26 \\
& $\mathrm{Al}_{2} \mathrm{O}_{3}$ & 99.90 & 99.70 \\
& & 0.8 & 4.0 \\
\hline
\end{tabular}

Table 3. Characteristics of Multiple-Organic Solution

\begin{tabular}{cccc}
\hline \hline Characteristics & Glycerin & Selosol 920 & Celuna D-305 \\
\hline Function & Plasticizer & Lubricant & Dispersant \\
Viscosity / cps at 298 K & -- & 6 & 50 \\
$\mathrm{pH} / 10 \%$ diluted solution & 6.7 & 5.8 & 7.0 \\
Density / $10^{3} \mathrm{~kg} \mathrm{~m}^{-3}$ & 1.22 & 0.95 & 1.24 \\
Suppliers & $\begin{array}{c}\text { Santoku Chem. } \\
\text { Com., Ltd. Japan }\end{array}$ & $\begin{array}{c}\text { Chukyo Oil } \\
\text { Co. Japan }\end{array}$ & $\begin{array}{c}\text { Chukyo Oil } \\
\text { Co. Japan }\end{array}$ \\
\hline
\end{tabular}

Table 4. Characteristics of PEG-10 k
Molecular Weight Range / $\mathrm{g} \mathrm{mol}^{-1}$

Melting Point Extent / K

Density $/ 10^{3} \mathrm{~kg} \mathrm{~m}^{-3}$
$9000 \sim 12500$

$331 \sim 336$ 
technique was used in determining the amount of glassy phase in the fired ceramics. ${ }^{18)}$ Samples were ground into powders (particle size $\leq 50 \mu \mathrm{m}$ ) and dried. About $10^{-3} \mathrm{~kg}$ (accurate to $10^{-7} \mathrm{~kg}$ ) of the samples was weighed and immersed in a leaching solution of 20 mass $\% \mathrm{HF}$ in water (10 $\mathrm{ml})$ at a leaching temperature of $291 \pm 0.2 \mathrm{~K}$ for a leaching time of $5 \mathrm{~h}$. The weight loss fraction $X_{\mathrm{d}}$ defined as

$$
X_{\mathrm{d}}=\left(W_{\mathrm{os}}-W_{\mathrm{r}}\right) W_{\mathrm{os}}{ }^{-1}
$$

can be obtained, where $W_{\text {os }}$ and $W_{\mathrm{r}}$ are the weights of the sample and the residue, respectively.

After determining the composition of the samples and the residues by chemical analysis, ${ }^{18)} X_{\mathrm{d}}$ can be written as

$$
X_{\mathrm{d}}=X_{\mathrm{g}}+D W_{\text {om }} \times W_{\text {os }}{ }^{-1}
$$

where $X_{\mathrm{g}}$ is the fraction of glassy phase, quartz and cristobalite in the sample, $W_{\text {om }}$ is the weight of mullite (determined by XRD data) in the sample and $D$ is the dissolved fraction of the mullite, which is defined as the quotient of the weight loss of mullite during leaching divided by the total amount of mullite in the sample. Since

$$
\begin{aligned}
& D W_{\text {om }}=W_{\text {om }}-W_{\text {rm }} \\
& W_{\text {rm }} S_{\mathrm{m}}=W_{\text {os }}\left(1-X_{\mathrm{d}}\right) S_{\mathrm{r}}
\end{aligned}
$$

Equation (5) can be rewritten as

$$
X_{\mathrm{g}}=X_{\mathrm{d}}-D S_{\mathrm{r}}\left(1-X_{\mathrm{d}}\right) S_{\mathrm{m}}^{-1}(1-D)^{-1}
$$

where $W_{\mathrm{rm}}$ is the weight of mullite in the residue, and $S_{\mathrm{r}}$ and $S_{\mathrm{m}}$ are the mass percentages of $\mathrm{SiO}_{2}$ in the residue and mullite, respectively.

\subsection{Material characterization}

The phases of the sintered kaolin- $\mathrm{SiO}_{2}-\mathrm{Al}_{2} \mathrm{O}_{3}$ samples were identified using an X-ray diffractometer (XRD) with $\mathrm{Cu} \mathrm{K} \alpha$ radiation and a $\mathrm{Ni}$ filter, operated at $30 \mathrm{kV}, 20$ $\mathrm{mA}$ and a scanning rate of $0.25^{\circ} \mathrm{min}^{-1}$ (Model XD-D1, Shimadzu, Japan). Mullite phase content was quantitatively determined based on the reflection of (121) in XRD data.

The morphology of the different phases of the sintered kaolin- $\mathrm{SiO}_{2}-\mathrm{Al}_{2} \mathrm{O}_{3}$ samples was observed by scanning electron microscopy (SEM; Model JSM-5200, JEOL Ltd., Tokyo) and the composition was analyzed by energy dispersive spectrometry (EDS; Model Noran Vantage, USA). The foils for transmission electron microscopy (TEM; Hitachi Model HF-2000 field emission transmission electron microscope, Hitachi Ltd., operated at $200 \mathrm{kV}$ ) were prepared by slicing to a thickness of about $30 \mu \mathrm{m}$ mechanically and ion-beam thinning to electron transparency.

\section{Results and discussion}

3.1 Phase analysis of sintered kaolin- $\mathrm{SiO}_{2}-\mathrm{Al}_{2} \mathrm{O}_{3}$ powder

The XRD patterns of the kaolin- $\mathrm{SiO}_{2}$ samples, to which 0.8- and $4.0-\mu \mathrm{m} \mathrm{Al}_{2} \mathrm{O}_{3}$ powders were separately added, sintered at various temperatures for $1 \mathrm{~h}$ are shown in Fig. 1 (i)-(vi). Mullite phase appears at approximately $1373 \mathrm{~K}$ and the integrated intensity of the index peak of mullite phase in the sintered samples increases with the increase in sintering temperature from 1373 to $1573 \mathrm{~K}$. Amorphous $\mathrm{SiO}_{2}$ changes to cristobalite above $1473 \mathrm{~K}$ and what increases with calcining temperature; however, the opposite trend has been observed for quartz. It is also found that the intensity of mullite phase in the sintered samples is the same in spite of the difference in $\mathrm{Al}_{2} \mathrm{O}_{3}$ the particle size used.

A standard for comparing the relative mullite phase content has been obtained by measuring the integrated intensity of the $(121)$ peak $\left(2 \theta=40.5^{\circ}\right.$ to $\left.41.5^{\circ}\right)$ for the mullite gels calcined at $1873 \mathrm{~K}$ for $24 \mathrm{~h}$. The relative mullite phase content for the sintered samples is shown in Fig. 2(a) as a func-

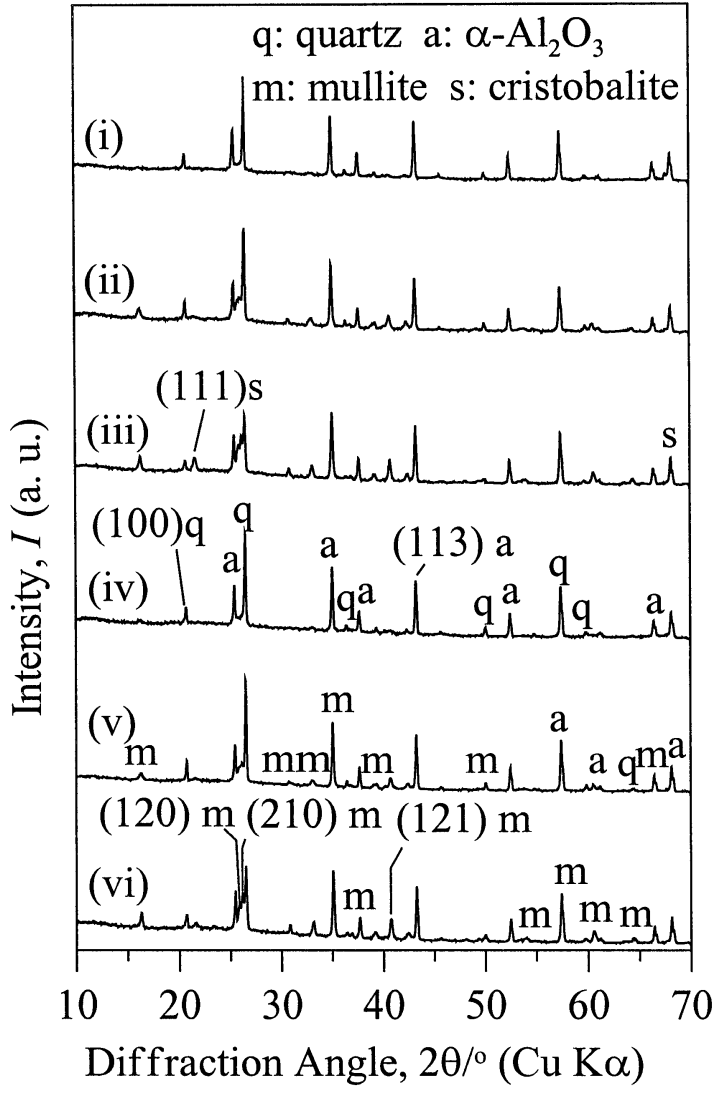

Fig. 1. XRD patterns of kaolin- $\mathrm{SiO}_{2}-\mathrm{Al}_{2} \mathrm{O}_{3}$ ceramics sintered at various temperatures for $1 \mathrm{~h} .0 .8-\mu \mathrm{m} \mathrm{Al} \mathrm{Ol}_{3}$ powder sintered at (i) 1373 , (ii) 1473 and (iii) $1573 \mathrm{~K} ; 4.0 \mu \mathrm{m} \mathrm{Al}{ }_{2} \mathrm{O}_{3}$ powder sintered at (iv) 1373 , (v) 1473 and (vi) $1573 \mathrm{~K}$.

tion of sintering temperature. The monosized primary mullite crystal as-sintered at temperatures below $1573 \mathrm{~K}$ is formed from decomposed metakaolinite, leaving $\alpha-\mathrm{Al}_{2} \mathrm{O}_{3}$ largely inert. ${ }^{11), 12)}$

The integrated intensity of the peak (113) $\left(2 \theta=43^{\circ}\right.$ to $44^{\circ}$ ) for $\alpha-\mathrm{Al}_{2} \mathrm{O}_{3}$ was used as a standard for comparing the relative $\alpha-\mathrm{Al}_{2} \mathrm{O}_{3}$ phase content. Figure $2(\mathrm{~b})$ shows the result of the kaolin- $\mathrm{SiO}_{2}-\mathrm{Al}_{2} \mathrm{O}_{3}$ compact sintered at 1373 to $1573 \mathrm{~K}$ for $1 \mathrm{~h}$, which indicate that $\alpha-\mathrm{Al}_{2} \mathrm{O}_{3}$ phase content does not change significantly irrespective of the $\mathrm{Al}_{2} \mathrm{O}_{3}$ particle size used for the compact sintered at 1373 to $1573 \mathrm{~K}$.

The dependence of glassy phase content on sintering temperature for samples containing $\mathrm{Al}_{2} \mathrm{O}_{3}$ powders of various particle sizes is shown in Fig. 3. As given in the XRD patterns in Fig. 1, the phases of quartz and cristobalite in the sintered samples were observed based on the reflections of (100) $\left(2 \theta=20^{\circ}-21^{\circ}\right)$ and (111) $\left(2 \theta=21^{\circ}-22^{\circ}\right)$ for quartz and cristobalite, respectively. This indicates that the glassy phase content decreases from about 49.4 to 17.7 mass $\%$ and 48.4 to 19.1 mass \% when the sintering temperature increases from 1373 to $1573 \mathrm{~K}$ for the 0.8 - and $4.0-\mu \mathrm{m} \mathrm{Al}_{2} \mathrm{O}_{3}$ powders, respectively.

When heated kaolin, transforms into mullite in several steps according to the reaction scheme below, and that the major mullite phase and the minor cristobalite phase contents are shown to increase with sintering temperature: ${ }^{19)-22)}$

$$
\begin{aligned}
& 6 \mathrm{SiAlO}_{3.5} \text { (spinel) } \stackrel{>1273 \mathrm{~K}}{\longrightarrow} 3 \mathrm{Al}_{2} \mathrm{O}_{3} . \\
& \left.2 \mathrm{SiO}_{2} \text { (mullite }\right)+4 \mathrm{SiO}_{2}(\text { amorphous })
\end{aligned}
$$




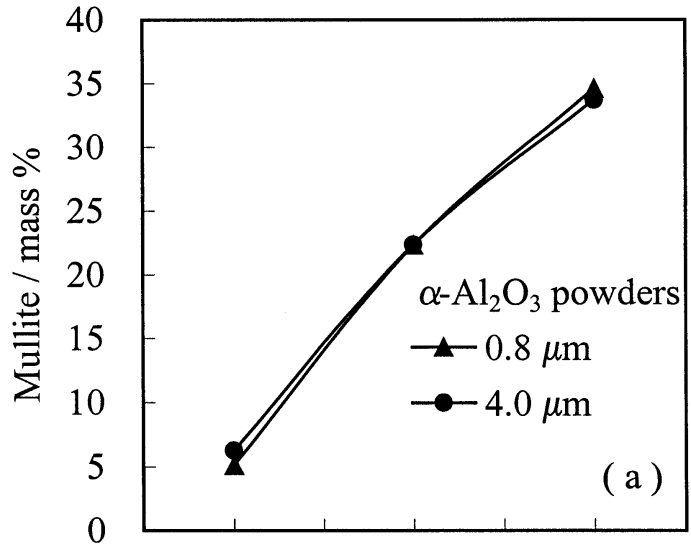

1323137314231473152315731623

Calcining Temperature / $\mathrm{K}$

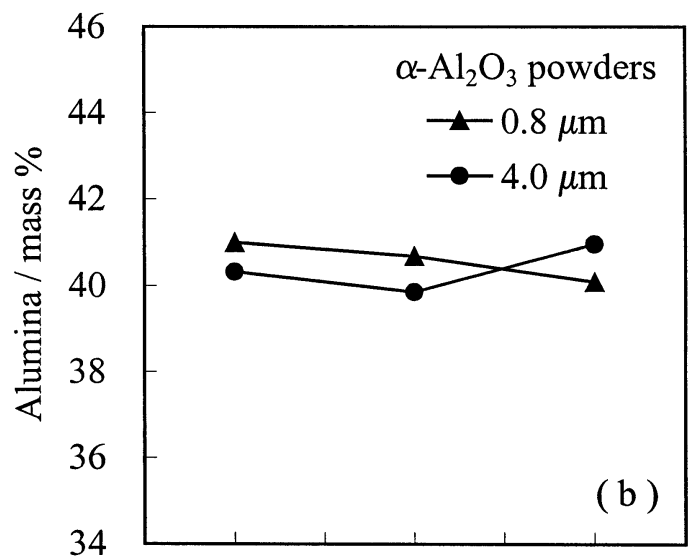

1323137314231473152315731623

Calcining Temperature / $\mathrm{K}$

Fig. 2. (a) Mullite and (b) $\mathrm{Al}_{2} \mathrm{O}_{3}$ phase content estimated by $\mathrm{XRD}$ analysis for the kaolin- $\mathrm{SiO}_{2}$ ceramics with $\mathrm{Al}_{2} \mathrm{O}_{3}$ powder of various particle sizes sintered at various temperatures for $1 \mathrm{~h}$.

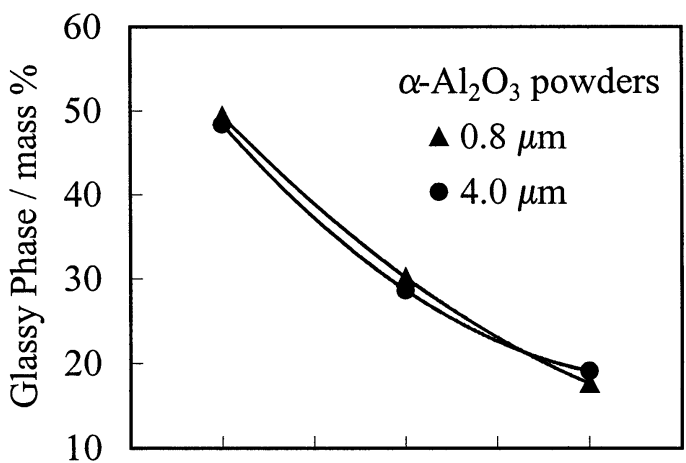

$13231373 \quad 14231473152315731623$

Calcining Temperature / K

Fig. 3. Glassy phase content estimated by $\mathrm{HF}$ acid leaching method in the kaolin- $\mathrm{SiO}_{2}$ ceramics with $\mathrm{Al}_{2} \mathrm{O}_{3}$ powder of various particle sizes sintered at various temperatures for $1 \mathrm{~h}$.
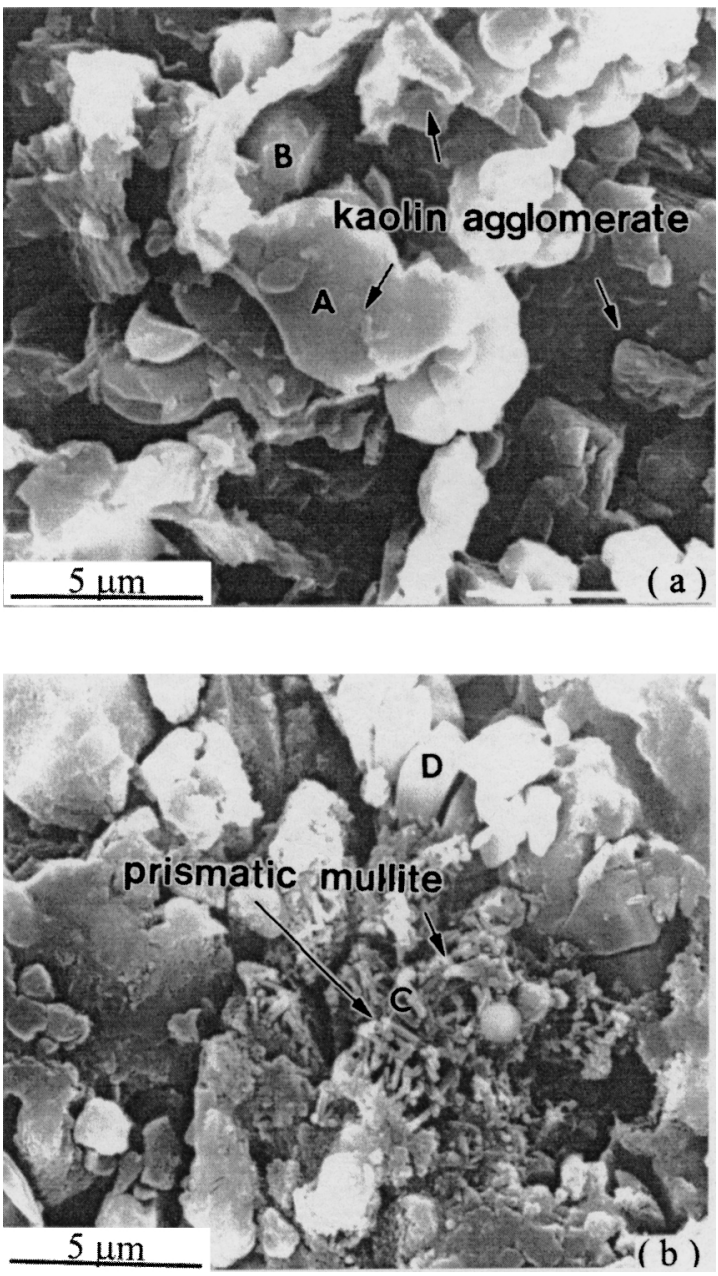

Fig. 4. SEM morphologies of kaolin- $\mathrm{SiO}_{2}$ ceramics with $4.0 \mu \mathrm{m}$ $\mathrm{Al}_{2} \mathrm{O}_{3}$ powder as-sintered at $1473 \mathrm{~K}$ for $1 \mathrm{~h}$ (a) before and (b) after $\mathrm{HF}$ acid etching.

$\mathrm{SiO}_{2}$ (amorphous) $\stackrel{>1473 \mathrm{~K}}{\longrightarrow} \mathrm{SiO}_{2}$ (cristobalite)

3.2 Microstructure of sintered kaolin- $\mathrm{SiO}_{2}-\mathrm{Al}_{2} \mathrm{O}_{3}$ powder

Figure 4 shows the SEM images of a ceramic body made of kaolin- $\mathrm{SiO}_{2}$ with $4.0 \mu \mathrm{m} \mathrm{Al} \mathrm{O}_{3}$ sintered at $1473 \mathrm{~K}$ for $1 \mathrm{~h}$. Chemical composition was determined at different locations of the sample sintered by EDS. Figure $4(\mathrm{a})$ shows the microstructure of the sample before etching and Table 5 lists the characteristic compositions for different locations in Fig. 4. It is found that the $\mathrm{Al}_{2} \mathrm{O}_{3}$ particles (location $\mathrm{B}$ ) dispersed in the matrix but kaolinite aggregated at location $\mathrm{A}$. Micron-sized platy kaolinite particles stuck together to form agglomerates so that lumps of glassy phase with a high Si content in round and irregular shapes were observed. Results in Tables 1 and 5 show that the lump with a high $\mathrm{Si}$ content in location A is composed of a mixture of kaolin and quartz.

Figure 4(b) shows the morphology of mullite grains in glassy phase which was removed by etching with concentrated $\mathrm{HF}$ acid. Location $\mathrm{C}$ shows the mullite composition and location $\mathrm{D}$ shows an $\mathrm{Al}_{2} \mathrm{O}_{3}$ particle. It is found that mullite grains in the sample sintered at $1473 \mathrm{~K}$ are shorter than $1.0 \mu \mathrm{m}$.

The TEM images of the compact of kaolin- $\mathrm{SiO}_{2}$ with 0.8 
Table 5. Chemical Composition of Locations in Fig. 4 by EDS

\begin{tabular}{ccccc}
\hline & \multicolumn{5}{c}{ Composition / mass \% } \\
\cline { 2 - 5 } Element & A & B & C & D \\
\hline Al & 32.0 & 96.1 & 80.2 & 97.9 \\
Si & 68.0 & 3.90 & 19.8 & 2.10 \\
\hline
\end{tabular}

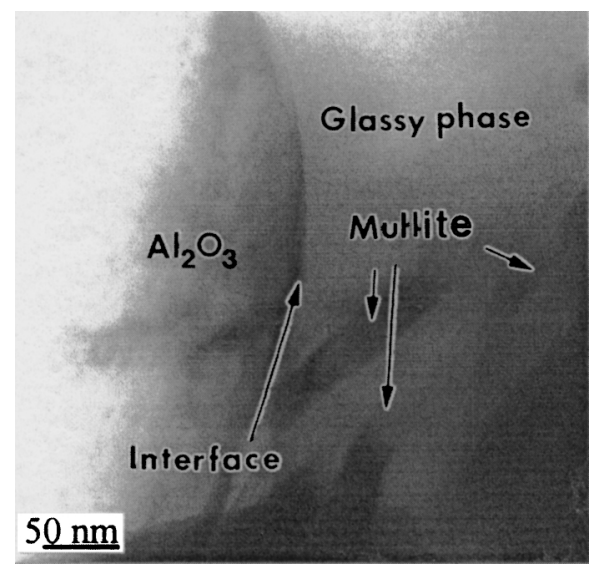

Fig. 5. TEM morphology of kaolin- $\mathrm{SiO}_{2}$ ceramics with $0.8-\mu \mathrm{m}$ $\mathrm{Al}_{2} \mathrm{O}_{3}$ powder as-sintered at $1573 \mathrm{~K}$ for $1 \mathrm{~h}$.

$\mu \mathrm{m} \mathrm{Al}_{2} \mathrm{O}_{3}$ sintered at $1573 \mathrm{~K}$ for $1 \mathrm{~h}$ are shown in Fig. 5 . It is noted that mullite particles are dispersed in glassy phase, which has been formed from the impurities in kaolin. The interface between the $\mathrm{Al}_{2} \mathrm{O}_{3}$ particle and glassy phase is still smooth and distinct showing that the reaction between the added $\mathrm{Al}_{2} \mathrm{O}_{3}$ particle and kaolin is very limited due to the relatively low sintering temperature.

\subsection{Open porosity and average pore size}

Figure 6 shows the dependence of open porosity on sintering temperature for the kaolin- $\mathrm{SiO}_{2}-\mathrm{Al}_{2} \mathrm{O}_{3}$ samples. The open porosity of the sintered samples with $0.8-\mu \mathrm{m} \mathrm{Al}_{2} \mathrm{O}_{3}$ powder decreases slightly from 48.4 to $43.1 \%$ when the sintering temperature increases from 1373 to $1473 \mathrm{~K}$. On the other hand, the open porosity practically remains unchanged from 46.8 to $46.2 \%$ for samples with $4.0-\mu \mathrm{m} \mathrm{Al}_{2} \mathrm{O}_{3}$ powder as the sintering temperature increases from 1373 to $1473 \mathrm{~K}$. In both samples, the open porosity decreases to $32.3 \%$, showing an improved sintering effect at the highest sintering temperature of $1573 \mathrm{~K}$.

The pore size distribution of the sample sintered at 1373 to $1573 \mathrm{~K}$ is shown in Fig. 7 (a), which shows a range from 0.05 to $1.0 \mu \mathrm{m}$. The intrusion volume of the sintered samples decreases with the increase in sintering temperature, this trend being similar to that of open porosity (as shown in Fig. 6). Pore growth is helpful in rending the broadening of pore size distribution when the samples are sintered at 1473 $\mathrm{K}$. The pores of the samples as-sintered at $1573 \mathrm{~K}$ tend to shrink by densification, which may result in a narrow pore size distribution.

The average pore size of the kaolin- $\mathrm{SiO}_{2}-\mathrm{Al}_{2} \mathrm{O}_{3}$ samples sintered at different temperatures for $1 \mathrm{~h}$ is shown in Fig. 7 (b). The average pore size readily increases from 0.32 to $0.51 \mu \mathrm{m}$ with the increase in temperature from 1373 to

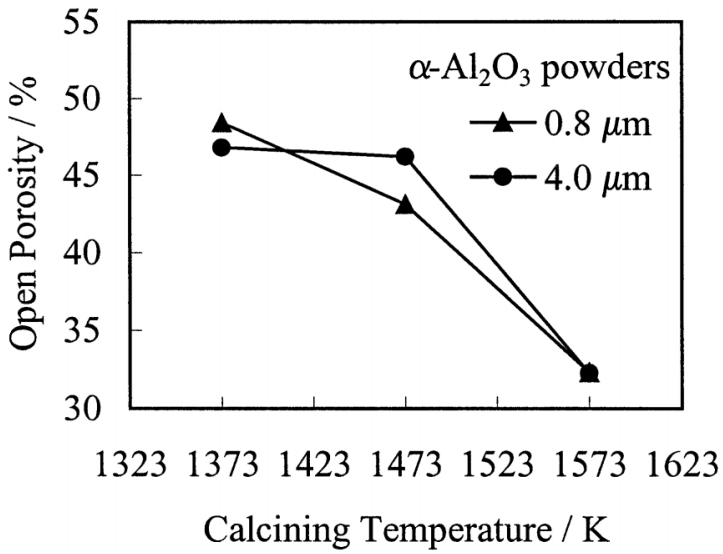

Fig. 6. Open porosity of the kaolin- $\mathrm{SiO}_{2}$ ceramics with $\mathrm{Al}_{2} \mathrm{O}_{3}$ powder of various particle sizes as-sintered at various temperatures for $1 \mathrm{~h}$.

$1473 \mathrm{~K}$ for the samples with $0.8-\mu \mathrm{m} \mathrm{Al}_{2} \mathrm{O}_{3}$ powders; it decreases to $0.28 \mu \mathrm{m}$ when the sintering temperature increases to $1573 \mathrm{~K}$. On the other hand, for the samples with $4.0 \mu \mathrm{m} \mathrm{Al}{ }_{2} \mathrm{O}_{3}$ powder, the average pore size increases from 0.32 to $0.63 \mu \mathrm{m}$ when the sintering temperature increases from 1373 to $1473 \mathrm{~K}$; it decreases to $0.56 \mu \mathrm{m}$ when the sintering temperature increases to $1573 \mathrm{~K}$.

3.4 Penetrating porosity and tortuosity of sintered kaolin- $\mathrm{SiO}_{2}-\mathrm{Al}_{2} \mathrm{O}_{3}$ ceramics

Figure 8 illustrates the pressure drop and sintering temperature dependence of the water volume flow rate of the kaolin- $\mathrm{SiO}_{2}$ samples with 0.8 - and $4-\mu \mathrm{m} \mathrm{Al}_{2} \mathrm{O}_{3}$ powders sintered at 1373,1473 and $1573 \mathrm{~K}$ for $1 \mathrm{~h}$. It is found that both water volume flow rate and pressure has a linear relationship that conforms to Darcy's law. Moreover, it is also found that at the same pressure, the sample as-sintered at $1473 \mathrm{~K}$ has a higher volume flow rate. In Fig. 7, this result is shown to be caused by the dependence of flow characteristic on pore size more than on porosity.

From Fig. 8, the maximum penetrating porosity of the $4.0-\mu \mathrm{m} \mathrm{Al}{ }_{2} \mathrm{O}_{3}$ powder sintered at $1373 \mathrm{~K}$ is $39.6 \%$ as calculated using Eq. (2). On the other hand, that of $0.8-\mu \mathrm{m} \mathrm{Al}_{2} \mathrm{O}_{3}$ sample sintered at $1473 \mathrm{~K}$ is only $24.1 \%$. During the formation of mullite and glassy phases, the number of open pores decreases and the penetrating porosity decreases to $9.4 \%$ for the samples with $4.0-\mu \mathrm{m} \mathrm{Al}_{2} \mathrm{O}_{3}$ powder as-sintered at $1573 \mathrm{~K}$. Open pores include nonpenetrating and penetrating pores that could be evaluated by the fluid permeation test. From Fig. 6 and Fig. 9, it may be generalized that open porosity is higher than penetrating porosity for the sintered samples.

The plot of $\varepsilon_{\text {eff }}$ (penetrating porosity) vs. $Q \cdot r^{-2}$ is shown in Fig. 10, being derived from Figs. 7 and 9. Penetrating porosity increases as the ratio of volumetric flow rate to average pore size squared increases. The slopes of the linear relationship are 3.32 and 3.79 for the samples with 0.8 - and 4.0- $\mu \mathrm{m} \mathrm{Al}_{2} \mathrm{O}_{3}$ powders, respectively. The slope of the ratio of volumetric flow rate to average pore size squared is shown to be in close agreement with Darcy's law that is based on Poiseulle's law of laminar flow through pores in liquid permeation of microporous materials.

Tortuosity $(\tau)$ is defined as the ratio of penetrating porosity to open porosity $(\varepsilon):^{1)}$

$$
\tau=\varepsilon_{\mathrm{eff}} \varepsilon^{-1}
$$

Figure 11 indicates that the tortuosity of the $0.8-\mu \mathrm{m} \mathrm{Al} \mathrm{O}_{3}$ powder does not significantly change for samples as-sin- 

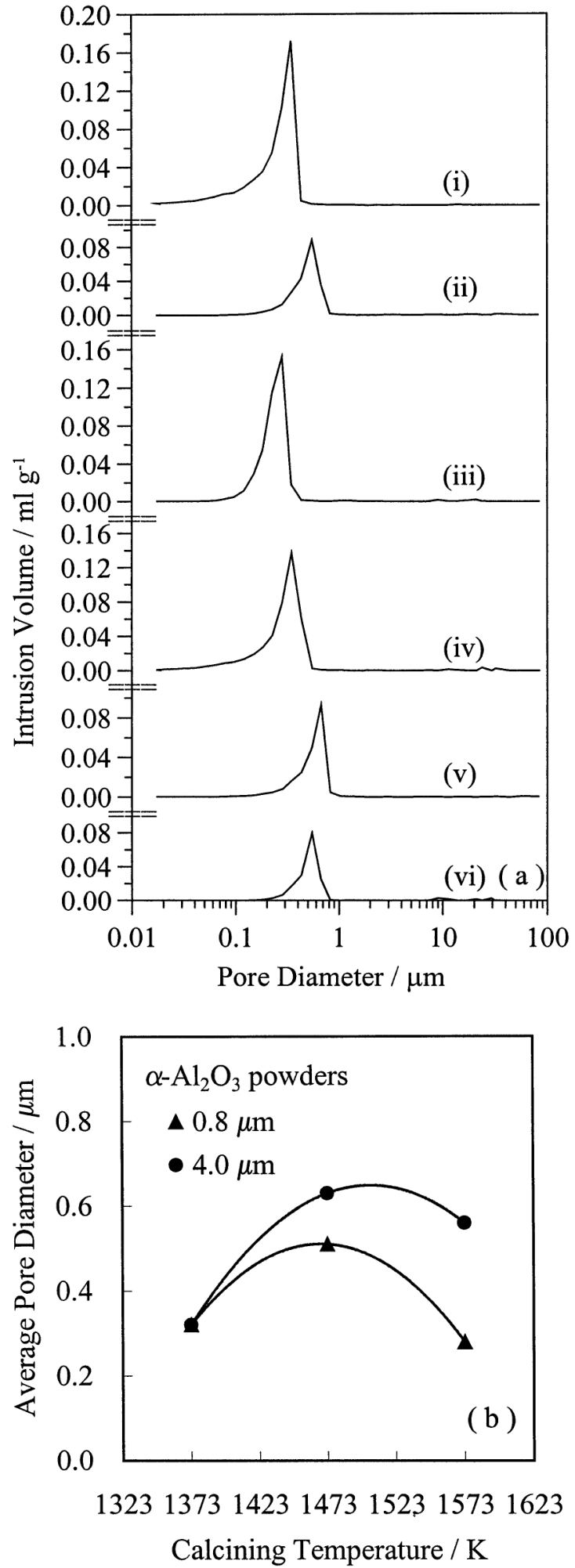

Fig. 7. Pore properties of sintered specimens. (a) Pore size distribution for $0.8-\mu \mathrm{m} \mathrm{Al} \mathrm{O}_{3}$ powder sintered at (i) 1373 , (ii) 1473 and (iii) $1573 \mathrm{~K} ; 4.0-\mu \mathrm{m} \mathrm{Al}_{2} \mathrm{O}_{3}$ powder sintered at (iv) 1373 , (v) 1473 and (vi) $1573 \mathrm{~K}$. (b) Average pore size of the kaolin- $\mathrm{SiO}_{2}$ ceramics with $\mathrm{Al}_{2} \mathrm{O}_{3}$ powder of various particle sizes sintered at various temperatures for $1 \mathrm{~h}$.

tered from 1373 to $1573 \mathrm{~K}$ for $1 \mathrm{~h}$. However, the tortuosity of the samples with $4.0-\mu \mathrm{m} \mathrm{Al}_{2} \mathrm{O}_{3}$ decreases from 0.85 to 0.29 when the sintering temperature increases from 1373 to
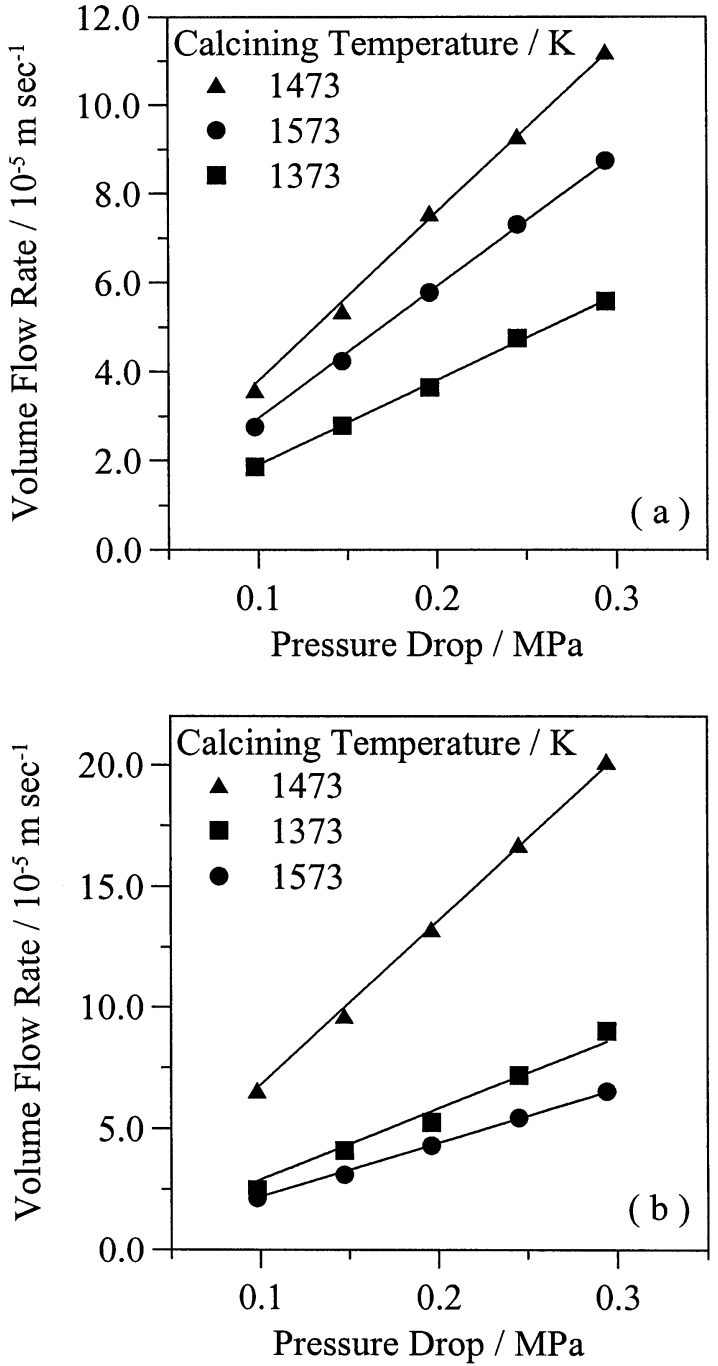

Fig. 8. Relationship between pressure, sintering temperature and the water volume flow rate of kaolin- $\mathrm{SiO}_{2}$ ceramics with (a) 0.8and (b) $4.0-\mu \mathrm{m} \mathrm{Al}_{2} \mathrm{O}_{3}$ powders sintered at various temperatures for $1 \mathrm{~h}$.

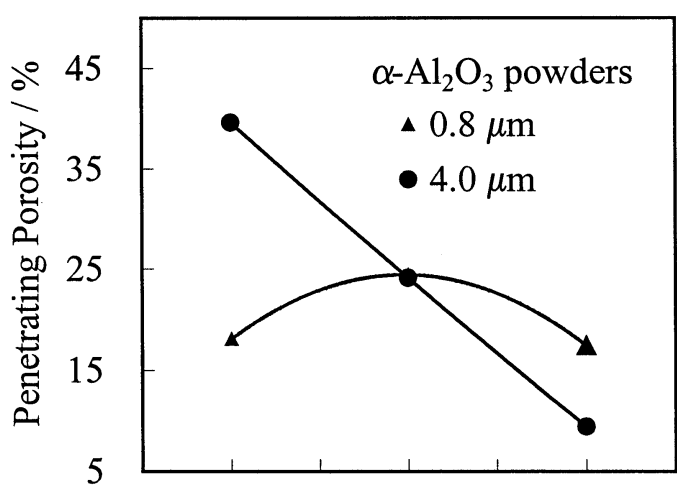

1323137314231473152315731623

Calcining Temperature / K

Fig. 9. Penetrating porosity of kaolin- $\mathrm{SiO}_{2}$ ceramics with $\mathrm{Al}_{2} \mathrm{O}_{3}$ powder of various particle sizes sintered at various temperatures for $1 \mathrm{~h}$. 


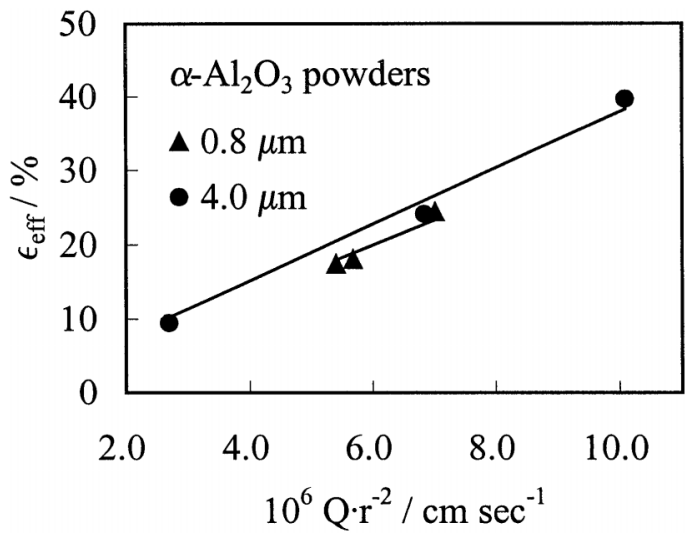

Fig. 10. $\varepsilon_{\text {eff }}$ vs. $Q \cdot r^{-2}$ for kaolin- $\mathrm{SiO}_{2}$ ceramics with $\mathrm{Al}_{2} \mathrm{O}_{3}$ powder of various particle sizes sintered at 1373 to $1573 \mathrm{~K}$ for $1 \mathrm{~h}$.

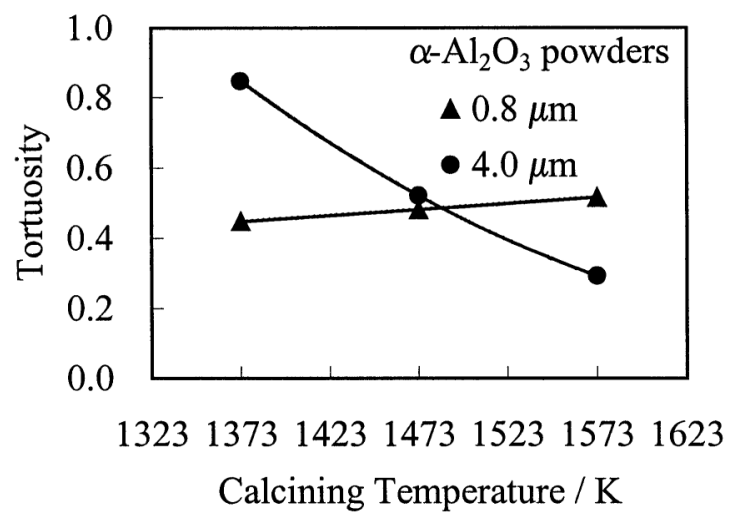

Fig. 11. Tortuosity of porous kaolin- $\mathrm{SiO}_{2}$ ceramics with $\mathrm{Al}_{2} \mathrm{O}_{3}$ powder of various particle sizes sintered at various temperatures for $1 \mathrm{~h}$.

\section{$1573 \mathrm{~K}$.}

The advantages of porous ceramic filters with a predominant mullite phase are that they have high fluid permeability, narrow pore size distribution and good thermal stability. From Figs. 7 (a), 9 and 11, narrow pore size distribution and penetrating porosity are important for porous filters, as they allow the selective removal of suspended particles by filtration. From Figs. $7(\mathrm{~b})$ and 11, sintered products with submicron-size pores could be used in sewage purification in the semiconductor industry or biomedical operations. Compared with different polymeric membrane materials ${ }^{23}$ and porous diatomite materials, ${ }^{24)}$ the mullitebased filtering material has been shown in this study to have a higher liquid permeability, which is considered to be due to its higher open porosity, narrower pore size distribution and larger pore diameter.

\section{Conclusions}

The results of this study are summarized as follows:

(1) Mullite phase content increases with the decrease in glassy phase content for the sintered kaolin- $\mathrm{SiO}_{2}-\mathrm{Al}_{2} \mathrm{O}_{3}$ samples when sintering temperature increases from 1373 to $1573 \mathrm{~K}$ for $1 \mathrm{~h}$.

(2) The open porosities of the sintered samples with 0.8- and 4.0- $\mu \mathrm{m} \mathrm{Al}_{2} \mathrm{O}_{3}$ powders decrease from 48.4 and $46.8 \%$ to $32.3 \%$ when the sintering temperature increases from 1373 to $1573 \mathrm{~K}$, respectively, and the pore size distri- bution ranges from 0.05 to $1.0 \mu \mathrm{m}$.

(3) The maximum penetrating porosity is $24.1 \%$ for the $0.8-\mu \mathrm{m} \mathrm{Al}_{2} \mathrm{O}_{3}$ powder as-sintered at $1473 \mathrm{~K}$ for $1 \mathrm{~h}$, but it decreases with the increase in sintering temperature for the 4.0- $\mu \mathrm{m} \mathrm{Al}_{2} \mathrm{O}_{3}$ powder system.

(4) The tortuosity for the $0.8-\mu \mathrm{m} \mathrm{Al}_{2} \mathrm{O}_{3}$ powder does not change significantly, but it decreases from 0.85 to 0.29 for the $4.0-\mu \mathrm{m} \mathrm{Al}_{2} \mathrm{O}_{3}$ powder when the sintering temperature increases from 1373 to $1573 \mathrm{~K}$.

(5) The mullite-based material prepared by sintering of a mixture kaolin- $\mathrm{SiO}_{2}-\mathrm{Al}_{2} \mathrm{O}_{3}$ has been shown to be a more effective filtering material than that of polymeric membrane materials and diatomite.

Acknowledgement Financial supports by the Chung-Shan Institute of Science \& Technology through contract number BV89B39P and the National Science Council of Taiwan, ROC. through grant No. 89-2216-E-006-072 are appreciated. The authors sincerely thank to Dr. H. C. Chang, Dr. C. L. Yang and Mr. L. H. Leu for their assistance in fluid permeation measurements and Dr. H. S. Liu for helpful discussion.

\section{References}

1) Ishizaki, K., Komarneni, S. and Nanko, M., "Porous Materials," Kluwer Academic Publisher, London (1998) pp. 214-218.

2) Das, N. and Maiti, H. S., J. Membr. Sci., Vol. 140, pp. 205-212 (1998)

3) Chan, K. K. and Brownstein, A. M., Am. Ceram. Soc. Bull., Vol. 70, pp. 703-707 (1991).

4) Hsieh, H. P., Bhave, R. R. and Felmming, H. L., J. Membr. Sci., Vol. 39, pp. 221-234 (1988).

5) Labot, A. P., Fabre, J. P., Guizard, C. and Cot, L., J. Membr. Sci., Vol. 39, pp. 203-220 (1988).

6) Štubn̆a, I. and Kozik, T., Ceram. Int., Vol. 23, pp. 247-249 (1996).

7) Pask, J. A. and Tomisa, A. P., J. Am. Ceram. Soc., Vol. 74, pp. 2367-2373 (1991).

8) Shkrabina, R. A., Boneckamp, B., Pex, P., Veringa, H. and Ismagilov, Z. R., React. Kinet. Catal. Lett., Vol. 54, pp. 181-191 (1995).

9) Liu, D. M., Ceram. Int., Vol. 23, pp. 513-520 (1997).

10) Chen, C. Y., Lan, G. S. and Tuan, W. H., Ceram. Int., Vol. 26, pp. 715-720 (2000).

11) Liu, K. C., Thomas, G., Caballero, A., Moya, J. S. and Aza, S. D., Acta. Metall. Mater., Vol. 42, pp. 489-495 (1994).

12) Sainz, M. A., Serrano, F. J., Amigo, J. M., Bastida, J. and Caballero, A., J. Eur. Ceram. Soc., Vol. 20, pp. 403-412 (2000).

13) Chen, C. Y., Lan, G. S. and Tuan, W. H., J. Eur. Ceram. Soc., Vol. 20, pp. 2519-2525 (2000).

14) Matsuda, O., Watari, T., Torikai, T., Yamasaki, Y. and Katsuki, H., J. Ceram. Soc. Japan., Vol. 100, pp. 725-730 (1992).

15) Kanka, B. and Schneider, H., J. Mater. Sci., Vol. 29, pp. 1239-1249 (1994).

16) Lukasiewicz, S. J. and Reed, J. S., J. Am. Ceram. Soc., Vol. 71, pp. 1008-1014 (1988).

17) Reed, J. S., J. Am. Ceram. Soc., Vol. 76, pp. 547-548 (1993).

18) Zhou, W., Zhang, L. and Fu, H., J. Am. Ceram. Soc., Vol. 71, pp. 395-398 (1988).

19) Carty, W. M. and Senapati, U., J. Am. Ceram. Soc., Vol. 81, pp. 3-23 (1998).

20) Brindly, G. W. and Nakahira, M., J. Am. Ceram. Soc., Vol. 40, pp. 346-350 (1957).

21) Brindly, G. W. and Nakahira, M., J. Am. Ceram. Soc., Vol. 42 , pp. 311-314 (1959).

22) Brindly, G. W. and Nakahira, M., J. Am. Ceram. Soc., Vol. 42, pp. 315-318 (1959).

23) Huisman, I. H., Dutré, B., Persson, K. M. and Trägårdh, G., Desalination, Vol. 113, pp. 95-103 (1997).

24) Vasconcelos, P. V., Labrincha, J. A. and Ferreira, J. M. F., J. Eur. Ceram. Soc., Vol. 20, pp. 201-207 (2000). 